\title{
THE HOME AS WORKPLACE: INVESTIGATING HOME BASED ENTERPRISES IN LOW INCOME SETTLEMENTS OF THE LAGOS METROPOLIS.
}

${ }^{*}$ LAWANSON, T. ${ }^{1}$ and OLANREWAJU, D. ${ }^{2}$

http://dx.doi.org/10.4314/ejesm.v5i4.9

Received 9th July 2012, accepted 11th August 2012

\begin{abstract}
The paper critically examines the phenomenon of Home Based Enterprises (HBE's) in low income residential areas of the Lagos Metropolis. The research adopts a purposive selection of thirty one low income residential neighbourhoods in the Lagos Metropolis. Data was obtained by the administration of structured questionnaires and analysis was done by both parametric and non-parametric methods. Random sampling of 394 home based enterprises was carried out. Issues examined include housing and environmental conditions; nature as well as types of home based enterprises and socioeconomic characteristics of operators. These include age, gender, and income, household size and level of education. The social network and informal institutions as well as the urban planning implications of these HBEs were also considered. The research revealed the importance of home based enterprises as a major source of income generation and socialization in urban areas. Recommendations include the adoption of case-specific planning models, consideration of cultural contexts in planning and the adoption of local economic development strategies in city design and development.
\end{abstract}

Key words: Poverty, Income, Lagos, Home, Workplace, HBEs, LED

\section{Introduction}

With $42 \%$ of Africa's population residing in cities, $20 \%$ of GDP and $60 \%$ of urban labour force is in the informal sector (Yunusa, 2011). Part of what allows informal-sector businesses to keep operating is their use of personal and domestic assets, such as living quarters, vehicles, and furniture for their business (Todaro, 1978; Lipton, 1980). Home based enterprises, also called Household enterprises or unincorporated enterprises owned by households are distinguished from corporations and quasicorporations on the basis of their legal status and the type of accounts they hold. They are not constituted as separate legal entities independently of the household or of household members that own them, and no complete set of accounts are available which could permit a clear distinction between the production activities of the enterprises and the other activities of their owners (Charmes 2000).

For Africa's urban poor populations, HBEs are an essential survival tool. HBEs provide work, income and services for so many people that they constitute an extremely important social and economic resource (Tipple, 2005). According to Chen (2009), the proportion of HBEs in all enterprises range from 54\% to $77 \%$ in Sub-Saharan Africa. Bose (2001) estimated that home based enterprises constitute $67 \%$ of the informal economy in Kano and $61 \%$ of that of Lagos. Such findings underscore the conclusion that the small-scale, micro-enterprise currently represents the most rapidly expanding employment segment of the contemporary African urban economy.

The focus on the Home Based enterprise is particularly important, as it is the easiest type of informal enterprise to engage in. The use of personal and domestic assets, such as living quarters, vehicles, and furniture for income generating activities as well as the possibility of transitioning from survivalist to growth enterprises over a relatively short period are clear advantages (Todaro, 1978; Lipton, 1980). Rogerson (1996) identified the micro-enterprise economy in urban Africa as consisting of two categories of informal enterprise. They are the survivalist enterprises, which represent a set of activities, undertaken by people unable to secure regular wage employment or access to an economic sector of their choice. The incomes generated from these enterprises fall short of minimum income standards and involve little capital investment, virtually no skills training, and only constrained opportunities for expansion into a viable business. Overall, poverty and the desperate attempt to survive are the prime defining features of these enterprises. Second are

${ }^{I}$ Department of Urban and Regional Planning, University of

Lagos, Nigeria

${ }^{2}$ Department of Urban and Regional Planning, Federal 
the growth enterprises, which are very small businesses, often, involving only the owner, some family members, and at most one to four paid employees. These enterprises usually lack all the trappings of formality, in terms of business licences, formal premises, operating permits, and accounting procedures, and most have only a limited capital base as well as rudimentary business skills among their operators. Literature further evidences links between home based activities and the alleviation of absolute poverty. These include the studies of Henry (1978), Gilbert (1988), Boris and Prügl (1996); Rogerson (2001) and Ighalo (2002). Others are those of Tipple (2005), Kilroy (2007) and Chen (2009). These have been reinforced by empirical studies of Sinai (1998), Ghafur (2002), Kachenje (2005), Nahiduzzaman (2006) and Oduwaye and Lawanson (2009) amongst others.

Home-based income generation is carried out within a given dwelling and its broader physical context (Ghafur, 2001). The hierarchical arrangement of spaces that are used in home-based income generation includes: the dwelling (meaning a house); its courtyard; the lane or street (immediate to a given dwelling) abode; the broader neighbourhood and, the public urban spaces. For the purpose of this study, the focus is on the home-based activities undertaken in the first, second and third space hierarchies, because of their direct impact on the environment and the planning of the residential space

The advantages of HBEs also include the ability to maintain an enterprise at little overhead cost and to make use of household resources, especially space and utility connections. Indeed, the home provides the ultimate environment for trading off resources between domestic and productive activities. These include the effective use of time, money and social resources. These can be achieved by avoiding travel to work as well as engaging relatives and friends to help out in exchange for small sums of money or benefits in kind. The home as workplace also enables women to engage in productive activities, especially in societies where their movement and social interactions are restricted.

This study investigates the nature and profile of Home Based Enterprises across low income settlements of the Lagos Metropolis. It attempts to determine how these enterprises thrive and the underlying framework for social and community development. It also investigates the urban planning issues that arise from their activities and how these can be effectively addressed in a dynamic and constantly evolving urban sphere. Study Area

The study is set in the Lagos Metropolis of Lagos state; South Western Nigeria. The study area comprises the 16 urban local government areas of Lagos State. They are Apapa, AjeromiIfelodun, Alimosho, Agege, Ifako-Ijaiye, Ikeja, Somolu, Eti-Osa, Oshodi-Isolo, Amuwo-Odofin, Kosofe, Ojo, Mushin, Lagos Mainland, Lagos Island and Surulere Local Government Areas of Lagos State respectively.

The Lagos metropolis is a group of islands endowed with creeks and a lagoon. It comprises settlements that have grown from predominantly farming and fishing villages to highly urbanized settlements. The Lagos Metropolis, home to more than $75 \%$ of the population of Lagos state, accounts for more than one third $(36.8 \%)$ of Nigeria's urban residents. It is the most populous conurbation in Nigeria and currently estimated to be the second fastest growing city in Africa and seventh fastest in the world. With a population of over 10 million people and population density of 20,000 persons/sq $\mathrm{km}$ it is regarded as a mega city (Mabogunje, 2002).

Lagos has remained the country's economic powerhouse, accounting for some $65 \%$ of Nigeria's industrial infrastructure and contributing more than half of national economic development (Okunlola 2007). Commercial activities have always been very strong in the city and are carried out at both the formal and informal levels (Abiodun, 1997). However, Lagos is presently characterized by commercial ribbon street development such that virtually all residential areas are in a chaotic state with indiscriminate mix of commercial, light industry, transport and religious land uses (Oduwaye, 2005). Thus over 100 blighted areas have been identified thus far, making up about $70 \%$ of the entire land area (Omirin and Nubi, 2007). According to Davis (2006), Lagos is simply the biggest node in the shantytown corridor of 70 million people that stretches from Abidjan to Ibadan: probably the biggest continuous footprint of urban poverty on earth. UNDP (2008) estimated that $51 \%$ of men and $54 \%$ of women resident in Lagos survive on less than US\$1 a day. The urban poor, who are dominant in Lagos, are transforming the city to meet their needs, often in conflict with official laws and plans. They are primarily engaged in 
informal economic activities, particularly home based enterprises. In fact, the Lagos State Government (2004) estimates that between 50\% and $75 \%$ of the residents of the Lagos Metropolis are employed in the informal sector, hence the focus of this study.

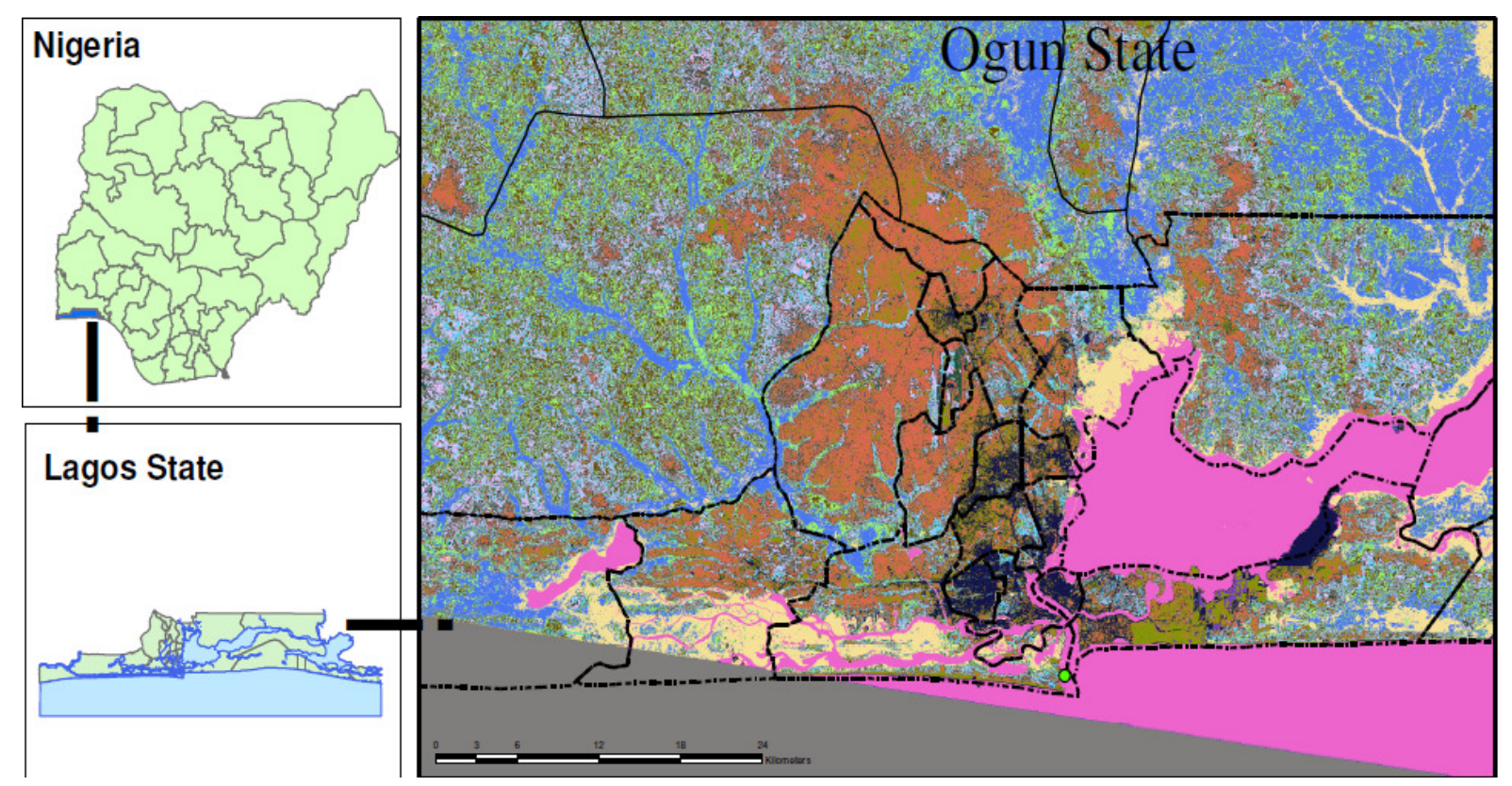

Figure 1 The Lagos Metropolis

Source: Nwokoro \& Dekolo (2012).

\section{Methodology}

The survey research strategy is adopted for this research. The study population are Home Based Enterprises (HBEs) operators in low income settlements across the Lagos metropolis. Small scale businesses located in and adjacent to residential buildings with multiple trade, service and production enterprises were sampled. Administration of structured questionnaires was by simple random sampling. These were administered in order to obtain data on components of poverty and livelihood. Questionnaires were structured to collate information on economic conditions and quality of life; socio-economic and socio-cultural peculiarities, environment and housing conditions.

Structured questionnaires were adminsitered on 553 home based enterprise operators in 31 selected neighbourhoods in the 16 local government areas that make up the Lagos Metropolis. Disproportionate stratified random sampling technique was adopted. The choice of particular wards and sample units was based on the authors knowledge of ther study area and reconnaisance survey.Neighbourhoods with a preponderance of home based enterprises as well as the multiplicity of home-based enterprises and the hierarchy of spaces in use for homebased enterprises were considered in order to ensure a normal distribution and as such a more reliable sample result. 394 questionnaires were retreived and analysed. Data analysis encompassed univariate analysis using descriptive statistics, bivariate analysis by adoption of the chi square test as well as analysis of variance tests.

\section{Results and Discussion \\ Household Characteristics of Respondents}

The most critical household characteristics considered are gender, age, educational attainment, and household size of respondents. The respondents consist of $53.78 \%$ male and $46.2 \%$ female. Results indicate that most of the respondents are within the working ages of 16 to 45 years, making up over $80 \%$ of the population. The population is relatively literate according to UNESCO standards which recognize anyone with at least secondary education as being literate, with about $73 \%$ having a minimum of secondary school education.

About $48 \%$ of the respondents live in Brazilian type rooming houses, sharing facilities with other residents. Average household size is 4-6 for the entire population. Households of between seven and nine make up about $15.91 \%$ 
of respondents. Large households of more than ten people comprise $3.78 \%$ of all the respondents and were particularly evident in neighbourhoods like Ajegunle (12) and Mushin (10) table 1.

Table 1 Household Characteristics of Respondents

\begin{tabular}{|c|c|c|c|}
\hline Variable & & $\mathrm{N}=394$ & $\%$ \\
\hline \multirow[t]{2}{*}{ Gender } & Male & 213 & 53.78 \\
\hline & Female & 183 & 46.22 \\
\hline \multirow[t]{5}{*}{ Age } & $\geq 15$ & 8 & 2.02 \\
\hline & $16-30$ & 165 & 41.66 \\
\hline & $31-45$ & 162 & 40.91 \\
\hline & $46-60$ & 50 & 12.63 \\
\hline & $\leq 61$ & 11 & 2.78 \\
\hline \multirow{4}{*}{$\begin{array}{l}\text { Highest level } \\
\text { of education } \\
\text { attained }\end{array}$} & No Formal & 30 & 7.58 \\
\hline & Primary School & 77 & 19.44 \\
\hline & Secondary School & 162 & 40.91 \\
\hline & Tertiary Education & 127 & 32.07 \\
\hline \multirow{4}{*}{$\begin{array}{l}\text { Household } \\
\text { size }\end{array}$} & $1-3$ & 94 & 23.74 \\
\hline & $4-6$ & 225 & 56.81 \\
\hline & $7-9$ & 63 & 15.91 \\
\hline & $\leq 10$ & 14 & 3.54 \\
\hline Housing & Owner occupied & 59 & 14.87 \\
\hline \multirow[t]{3}{*}{ Tenureship } & family owned & 47 & 11.84 \\
\hline & Tenant & 275 & 69.30 \\
\hline & Squatter & 15 & 3.78 \\
\hline Rooms for & 1 & 81 & 20.41 \\
\hline exclusive & 2 & 142 & 35.78 \\
\hline household & 3 & 123 & 30.99 \\
\hline use & $<4$ & 50 & 12.60 \\
\hline No of & 1 & 24 & 3.05 \\
\hline households & $2-4$ & 96 & 24.19 \\
\hline in the & $5-8$ & 202 & 60.90 \\
\hline \multirow[t]{2}{*}{ buildings } & $9-12$ & 52 & 13.10 \\
\hline & $<13$ & 22 & $\begin{array}{r}4 \\
554\end{array}$ \\
\hline
\end{tabular}

In comparing the means across the neighbourhoods, One sample statistics show that $P$ value for access to basic household facilities are significant at $\mathrm{P}<.05$. That means that there is a significant intra-group variation in the access to basic housing and environmental facilities. The decision rule is that if $\mathrm{P}-\mathrm{V}$ alue is less than $\alpha=0.05$, reject the null hypothesis, otherwise accept. Since P-values for all the variables are all less than $\alpha=0.05$, the conclusion is to reject the null hypothesis and accept the alternative which states that there is a difference between the mean across neighbourhoods in at least one of the neighbourhoods.

\section{Employment Structure}

Almost $80 \%$ of the respondents are employed in the informal sector exclusively. Only about $20 \%$ of the respondents are employed in the formal sector. $10 \%$ are employed by both government and private concerns. Because of lack of educational qualifications, most of these jobs are low paying junior staff employments such as janitor, office assistants etc.

About half of all respondents are involved in informal trade activities. These range from petty trading to hawking to selling of cooked food and raw farm produce and other minor household items. Informal service sector accounts for 39\% of the respondents. These activities include hairdressing and barbing, tailoring, secretarial services, horology, sign writing, photography and auto repair services. Informal manufacturing is done by only $7 \%$ of the respondents and includes cobbling, production of sachet water and packed food, nylon production, crafts, carpentry and metal works. This disparity may be due to the fact that skills are required for services and manufacturing. They are also relatively capital intensive since one will need to purchase equipment and plants to operate in the subsector. 
Table 2 also shows that more than $70 \%$ of the businesses are sole proprietorships which is the nature of most informal survivalist enterprises that dominate the entire study area. Partnerships account for about $24 \%$ of all businesses. The high value recorded in the high density areas may be because of the need to combine incomes in order to break even and transit from survivalist to transition enterprises. Over $70 \%$ of the enterprises employ between one and four apprentices, mostly members of their families. Unpaid family workers make up about $8 \%$ of the staff strength. Over $80 \%$ of the respondents run kinship based enterprises in which the ownership of the business lies with them and/or members of their families. Owner managed businesses in the high density areas account for 71.37 of all businesses sampled.

Table 2 Employment Profile of Respondents

\begin{tabular}{|c|c|c|c|}
\hline & & $\mathrm{N}=394$ & $\%$ \\
\hline \multirow{3}{*}{$\begin{array}{l}\text { Nature of } \\
\text { employment }\end{array}$} & Not formally employed & 312 & 79.25 \\
\hline & Government employed & 40 & 10.16 \\
\hline & Private Employed & 42 & 10.67 \\
\hline \multirow{3}{*}{$\begin{array}{l}\text { Category of } \\
\text { informal } \\
\text { sector }\end{array}$} & Trade & 193 & 49.02 \\
\hline & Service & 156 & 39.62 \\
\hline & Manufacturing & 30 & 7.62 \\
\hline \multirow{3}{*}{$\begin{array}{l}\text { Nature of } \\
\text { business }\end{array}$} & Sole Proprietorship & 292 & 74.17 \\
\hline & Partnership & 97 & 24.64 \\
\hline & Family owned & 71 & 18.03 \\
\hline \multirow{4}{*}{$\begin{array}{l}\text { Business } \\
\text { registration }\end{array}$} & Not registered & 234 & 59.44 \\
\hline & Local Govt trade permit & 100 & 25.40 \\
\hline & Lagos state govt & 7 & 1.78 \\
\hline & Corporate Affairs Commission & 44 & 11.18 \\
\hline \multirow{5}{*}{$\begin{array}{l}\text { Source of } \\
\text { business } \\
\text { funding }\end{array}$} & Bank loan & 2 & 0.51 \\
\hline & Thrift & 199 & 50.55 \\
\hline & Cooperative loan & 134 & 34.03 \\
\hline & Savings & 162 & 41.15 \\
\hline & Family aid & 84 & 21.34 \\
\hline \multirow{3}{*}{$\begin{array}{l}\text { Position in } \\
\text { business }\end{array}$} & Owner & 281 & 71.37 \\
\hline & Paid employee/ Apprentice & 79 & 20.07 \\
\hline & Unpaid family worker & 35 & 8.89 \\
\hline \multirow{4}{*}{$\begin{array}{l}\text { Staff } \\
\text { strength }\end{array}$} & 1 & 131 & 33.27 \\
\hline & $2-4$ & 181 & 45.97 \\
\hline & $5-7$ & 37 & 9.40 \\
\hline & $\leq 8$ & 37 & 9.40 \\
\hline
\end{tabular}

Almost $60 \%$ of the businesses have no form of registration with appropriate authorities. About $25 \%$ have local government trade permits; while only $11 \%$ of the respondents have registered their businesses with the Corporate Affairs Commission. The major sources of funding for most of the businesses are a combination of savings, thrift and cooperative loans. Only two respondents making up less than $1 \%$ have ever taken bank loans and this is because of the high interest rates and the difficulty of getting collaterals. Furthermore, most of the businesses are quite small and lack legal status and so are unable to access credit. $34 \%$ of respondents have obtained cooperative society loans, which were repaid within twelve months. They expressed satisfaction with the procedure and method of payment as well as the flexible interest rates.

Participation in social groups (cooperative/ thrift society and/or local chapter of artisans association) was discovered to be a key parameter for the survival of the HBEs in the study area. These groups are the social security mechanism in place for low income earners. The key variables considered were membership of social groups, as well as knowledge and participation in poverty alleviation programmes. It was discovered that $61 \%$ of respondents belong to social groups. . These social groups, usually under the aegis of crafts and tradesmen associations double as cooperative, credit and thrift societies. The respondents were asked to rank the various poverty alleviation programmes 
in order of effectiveness and sustainability. the respondents were mainly interested in the following groups activities in order of priority Self-help groups; faith based organization; Lagos State Government; Federal Government. While the government programmes were structured, selection of participants was based on political affiliation. Only $45 \%$ of respondents had participated in any poverty alleviation programmes.

In order to determine if there is any significant difference the various types of poverty alleviation programmes, the test of homogeneity of variance was done. The results are shown in Table 3 below.

Table 3 Test of Homogeneity of Variance of Types of Poverty Alleviation Programmes

\begin{tabular}{lllll}
\hline & $\begin{array}{l}\text { Levene } \\
\text { statistic }\end{array}$ & Df1 & Df2 & sig \\
Government & 7.744 & 47 & 594 & .000 \\
NGO & 6.903 & 46 & 588 & .000 \\
Religious organizations & 10.499 & 46 & 594 & .000 \\
Cooperative societies & 10.071 & 47 & 594 & .000 \\
Self help organizations & 7.696 & 47 & 603 & .000 \\
\hline
\end{tabular}

Since the P-Values are all less than $\alpha=.05$, the conclusion is that there is difference in homogeneity of variances occurs in at least one of the sampled neighbourhoods.

\section{Income and Asset Ownership of Respondents}

The major variables tested here are possession of basic assets i.e. car, motorcycle, ownership of land or house. Data was also gathered on the number of additional income earners in the family as well as number of streams of income. Incomes from home enterprise and other sources are also gathered.

Table 3 revealed that about $49 \%$ of the respondents rely solely on their home enterprises. The modal monthly income from home enterprises is $\$ 7,500-\$ 15,000$. This accounts for about $29.21 \%$ of respondents. With $53.85 \%$ of respondents earn less than $\$ 15,000$ monthly from their home enterprise, while $24.64 \%$ earn below the national minimum wage of $\$ 7,500$, this set of people automatically fall under the absolute poor category.

Respondents rely on multiple streams of income for survival. About $20 \%$ of respondents are also employed in the formal sector of the economy, particularly as junior staff in government organizations. Other sources of income include income from abroad (16.5\%) and returns from thrift/ cooperative collaborations (24.9\%). This confirms the generally held view that cooperative societies are the insurance of the low income earner. Other members of the family also contribute to family survival. They include spouses (69\%), children (17.5\%) and other relatives (13.46\%).

When asked about possession of assets, over half of the respondents returned positive answers for house and land, even though most of them claimed such landed properties were located in their home towns and villages. About $40 \%$ of respondents own cars or motorcycles, most of which are used for income generation as taxicabs, kabukabu or okada.

On possession of household items, a clear demarcation could not be determined on which assets are used for business and which are used exclusively for the household. An example is the electricity generating set. Over $64 \%$ of the respondents own electricity generating sets, primarily because they consider it as essential for their business survival. However, these sets are also used in the household after the business day is over. While all respondents have electric fans, only $3.5 \%$ own air conditioners, which are considered as business incentives mainly for those in commercial business centres. The DVD player is considered an essential item for recreation; hence more than $80 \%$ of the respondents in the study area own them. The proliferation of cheap imported/ second hand items makes the possession of household item such as television, compact disc player and refrigerator easily accessible to most households.

The relationships between income levels and informal employment characteristics are further corroborated by chi-square tests. Results show that there are significant differences in the nature of business and type of business registration as well as source of business funding 
Table 4 Income and Asset Ownership Profile of Respondents

\begin{tabular}{|c|c|c|c|}
\hline Variable & \multicolumn{2}{|c|}{$\mathrm{N}=394$} & $\%$ \\
\hline \multirow{5}{*}{$\begin{array}{l}\text { Monthly } \\
\text { income from } \\
\text { home } \\
\text { enterprise }\end{array}$} & $\leq \$ 7,500$ & 97 & 24.64 \\
\hline & $\$ 7,500-\$ 15,000$ & 115 & 29.21 \\
\hline & $\$ 15,000-\$ 30,000$ & 94 & 23.59 \\
\hline & $\$ 30,000-\$ 60,000$ & 61 & 15.49 \\
\hline & $\geq N 60,000$ & 27 & 6.86 \\
\hline \multirow{6}{*}{$\begin{array}{l}\text { Monthly } \\
\text { income from } \\
\text { other sources }\end{array}$} & None & 201 & 51.05 \\
\hline & $\leq \$ 7,500$ & 51 & 12.95 \\
\hline & $\$ 7,500-\$ 15,000$ & 60 & 15.24 \\
\hline & $\$ 15,000-\$ 30,000$ & 51 & 12.95 \\
\hline & $\$ 30,000-\$ 60,000$ & 21 & 5.334 \\
\hline & $\geq \$ 60,000$ & 10 & 2.54 \\
\hline \multirow{5}{*}{$\begin{array}{l}\text { Other Income } \\
\text { Source }\end{array}$} & Office Job & 82 & 20.83 \\
\hline & Inheritance & 38 & 9.65 \\
\hline & Rent & 17 & 4.32 \\
\hline & Income from Abroad & 65 & 16.51 \\
\hline & Cooperatives/ Thrift & 98 & 24.89 \\
\hline \multirow{3}{*}{$\begin{array}{l}\text { Other family } \\
\text { income earner }\end{array}$} & Spouse & 272 & 69.08 \\
\hline & Children & 69 & 17.53 \\
\hline & Relatives & 53 & 13.46 \\
\hline \multirow{4}{*}{$\begin{array}{l}\text { Possession of } \\
\text { assets }\end{array}$} & Land & 213 & 53.79 \\
\hline & House & 210 & 53.03 \\
\hline & Car & 119 & 30.05 \\
\hline & motorcycle & 41 & 10.35 \\
\hline \multirow{6}{*}{$\begin{array}{l}\text { Possession of } \\
\text { household } \\
\text { items }\end{array}$} & Generator & 257 & 64.89 \\
\hline & Air conditioner & 14 & 3.53 \\
\hline & Electric Cooker & 123 & 31.06 \\
\hline & Deep Freezer & 182 & 45.96 \\
\hline & DVD Player & 335 & 84.60 \\
\hline & Electric kettle & 218 & 55.50 \\
\hline
\end{tabular}

\section{Home and Workplace Linkages}

To determine the relationship between variables of deprivation and participation in home based enterprises, the Zero-order Pearson correlation matrix was used. Both the informal participation and deprivation variables were used as control variables and their results were compared

When variables of informal participation are held constant, significant positive correlationships exist between income from primary employment and house ownership as well as car ownership and source of funding. Income from secondary employment a majority of the enterprises employ between one and four apprentices. Business location is usually rented shops for about $75 \%$ of the respondents, with about $9 \%$ of them operating along the street. About $6 \%$ of respondents use part of their living quarters for their enterprise. More than $90 \%$ of the respondents live within the vicinity of their businesses. i.e. less than $2 \mathrm{~km}$ from their business premises

When deprivation factors are held constant, there are not significant correlation values, although type of business and source of business funding have a very small positive correlation. Position in business is moderately positively correlated with type of business. Business registration has a negligible negative correlationship with business funding, type of business and position in business. It can be inferred therefore poverty and informal sector participation are related in that informal enterprises has a great influence on the level of poverty. 
Table 5 Correlates of Participation in HBEs and Deprivation

\begin{tabular}{|c|c|c|c|c|c|c|c|c|c|c|}
\hline &  & 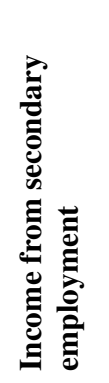 & 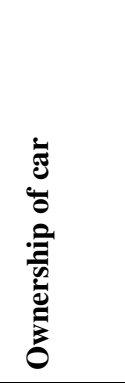 & 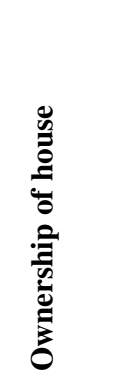 & 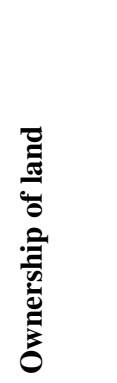 & 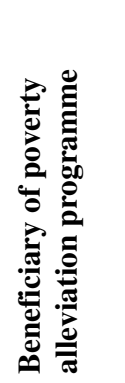 & 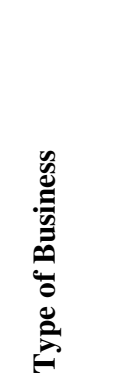 & 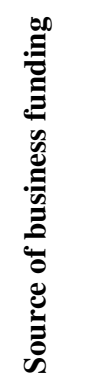 &  & 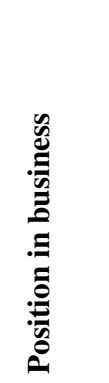 \\
\hline $\begin{array}{ll}\text { Income from Primary } \\
\text { Employment }\end{array}$ & 1.000 & 0.365 & -0.516 & $-0.192 *$ & 0.018 & -0.100 & 0.041 & -0.283 & -0.006 & -0.270 \\
\hline $\begin{array}{l}\text { Income from secondary } \\
\text { employment }\end{array}$ & & 1.000 & -0.207 & -0.281 & -0.118 & -0.203 & 0.102 & -0.308 & -0.091 & -0.035 \\
\hline Ownership of car & & & 1.000 & 0.216 & 0.030 & 0.114 & $-0.149 *$ & 0.138 & 0.114 & 0.073 \\
\hline Ownership of house & & & & 1.000 & 0.769 & 0.028 & 0.019 & 0.118 & 0.101 & 0.090 \\
\hline Ownership of land & & & & & 1.000 & -0.016 & 0.073 & -0.018 & -0.019 & 0.065 \\
\hline $\begin{array}{l}\text { Beneficiary of poverty } \\
\text { alleviation programme }\end{array}$ & & & & & & 1.000 & $0.159 *$ & 0.233 & $0.171 *$ & 0.031 \\
\hline Type of Business & & & & & & & 1.000 & 0.001 & -0.057 & 0.318 \\
\hline $\begin{array}{l}\text { Source of business } \\
\text { funding }\end{array}$ & & & & & & & & 1.000 & $0-052$ & 0.093 \\
\hline Business registration & & & & & & & & & 1.000 & -0.123 \\
\hline Position in business & & & & & & & & & & 1.0000 \\
\hline
\end{tabular}

${ }^{*}$ correlates are significant 0.05 


\section{Recommendations}

The study revealed that home based enterprises offer a means of survival to many who would otherwise have been unemployed. Participating in HBEs provide a reliable social security framework for the low income neighbourhoods, in addition to providing finance and other institutional support for transiting from survivalist to growth enterprises.

The challenge therefore is how city managers can harness the potentials of this ubiquitous urban phenomenon. Urban and regional planning has a significant role to play in ensuring that communities continually upgrade to improve their global relevance and local standards. Planning strategies to enhance local economic development, poverty alleviation and environmental sustainability must be deployed.

Key to the Sustainable Livelihoods concept is Pro-poor planning which advocates an integration of community development efforts with urban economic development strategies. The neighbourhoods surveyed are suffering from economic insufficiency as well as environmental decline, hence the need to ensure employment opportunities, to supply necessary public and private infrastructure, thereby improving quality of life.

The role of local economic development within a community includes setting up, running, and supporting an endogenous network able to catalyze development. The essential mission of LED agencies is to create jobs, promote and support small and mediumsized enterprises, improve the economic context and opportunity of the territory and use businesses as a weapon in the fight against poverty. LED initiatives include ensuring the functionality of local investment climate in order to boost local businesses, the encouragement of new enterprise, attracting outside investments and investing in physical infrastructure. Other strategies involve human resource development and institutional support systems, supporting the growth of particular clusters of businesses, targeting certain disadvantaged groups and particular parts of the city for regeneration and supporting survivalist businesses.
Settlement upgrading should integrate economic, social, legal, financial elements of development, creating conditions that enable community action. Nongovernmental organizations also have a part to play in that in acting as facilitators, they can serve to bridge the gaps between the communities' and municipalities

Community Development is the empowerment of people, of organizations and of communities to attain or restore viability. It does so by motivating change in the nature and stocks of both social and economic capital. Such an approach is tantamount to a sort of indigenous development, in which local resources are assembled to kick-start the progression that would bring prosperity to places where it is initially in short supply. Community Development is a means for evoking participation of community members to muster resources and coordinate their strategic usage in support of community-based goals. Community development aims not only to elicit the character of a desired future through community involvement in decisionmaking, but also seeks to harness the community in attracting needed resources and nurturing social capital gains.

It is essential that Pro-poor Planning Strategies must be adopted for the planning of cities and new towns. Physical planning of the city must be placed at the service of the fight against poverty, creating a facilitating environment for the development of informal activities, by delineating certain areas as market areas within residential neighbourhoods, encouraging mixed use development and making provision for light industrial areas to serve cottage industries

\section{Conclusion}

About $70 \%$ of the 17 million residents of Lagos metropolis are considered poor, and can only survive by participating in informal activities, starting from the basic level of home based enterprises.

Home based enterprises have a positive effect on both average household income and the general welfare of the local neighbourhood. The study revealed the social security mechanisms inherent in social groups 
that are formed around these HBEs help in local economic development as well as community engagement.

Ensuring that city improvement policies assist the viability of HBEs and accept them as a reality of urban life will aid in helping low income communities achieve sustainable development which can be interpreted to economic development, employment opportunities and social progress, in harmony with the environment (ICLEI, 1996).

\section{References}

Abiodun, J. (1997), The Challenges of Growth and Development in Metropolitan Lagos. In Rakodi, C. (ed.) The Urban Challenge in Africa: Growth and Management of its Large Cities. Tokyo: United Nations University Press.

Boris, E. and Prügl, E. (eds.), (1996). Homeworkers in Global Perspective: Invisible No More. New York, Routledge.

Bose, M. (2001), The Urban Informal Sector Revisited: Some Lessons from the Field'. Sussex: Institute of Development Studies Charmes, J. (2000).Informal Sector, Poverty, and Gender: A Review of Empirical Evidence. Paper commissioned for World Development Report 2000/2001. Washington D.C: World Bank.

Chen, M. (2009), Global Recession and the Informal economy: Evidence from Latin America www.wiego.org. Retrieved June $4^{\text {th }}$ 2009

Davis, M. (2006), Slum like it not: in the world's slums, the worst of poverty and environmental degradation collide. www.oriononline.com .

Ghafur, S. (2001), Beyond Homemaking: The role of slum improvement in home based income generation in Bangladesh; Third world Planning review. 111-135

Ghafur, S. (2002), Gender Implications of space use in home based work; in Habitat International 26 (1)33-50

Gilbert, A. (1988), Home enterprises in poor urban settlements: constraints, potentials and policy options Regional Development Dialogue 9(4)21-37

Henry, S. (1978). The Hidden Economy. London: Martin Robertson.
Ighalo, J. (2002), The Urban Economy, Urban Growth and Change"; in Amole. D (ed)The City in Nigeria. Ile Ife: Faculty of Environmental Design and Management. 4364

International Council for Local Environmental Initiatives (ICLEI) (1996) The Local Agenda 21 Planning Guide: An Introduction to Sustainable Development Planning.

Kachenje, Y. (2005), Home-based enterprises in informal settlements of Dar es Salaam, Tanzania. being unpublished Master of Science thesis in Built Environment Analysis, Department of Urban and Regional Planning, Royal Institute of Technology, Stockholm, Sweden

Kilroy, A. (2007), Intra-urban spatial inequalities: cities as 'urban regions'. Background paper for World Development Report 2009. www.imit.edu retrieved October $4^{\text {th }} 2010$

Lagos State Government/ UN-Habitat Office in Nigeria (2004) State of the Lagos Megacity and other Nigerian cities Report

Lipton, M. (1980), Family, fungibility and formality: rural advantages of informal nonfarm enterprise versus the urban formal state", in Amin, S. (ed.) Human Resources, Employment and Development Vol 5, Developing countries. London: Macmillan

Mabogunje, A. (2002), Re-constructing the Nigerian City: The New Policy on Urban Development and Housing, Paper presented at a National Conference on the City in Nigeria , Ile Ife

Nahiduzzaman, K. (2006), Housing the Urban Poor: Planning, Business and Politics: A case study of Duaripara Slum, Dhaka City, Bangladesh. Unpublished Master of Philosophy Thesis in Development Studies, Norwegian University of Science and Technology

Nwokoro, I., \& Dekolo, S . (2012), Land Use Change and Environmental Sustainability: the Case of Lagos Metropolis. In M. Pacetti, G. Passerini, C. A. Brebbia, \& G. Latini (Eds.), Sustainable City VII (Vol. 2, pp. 157-168). Southampton, United Kingdom: WIT Press Oduwaye, A. (2005), 'Rezoning Residential Areas in Metropolitan Lagos as a Strategy Toward Increasing Housing Stock', Journal 
of Association of Housing Corporation of Nigeria, 1(9), 18-22.

Oduwaye, A. and Lawanson, T. (2009): Land Use Development, Planning Administration and Planning Education in the Lagos Metropolis, presented at University of Lagos Research Conference and fair

Okunlola, P. (2007). 'The Power and the Heartbeat of West Africa's Biggest Urban Jungle". UN-Habitat Feature paper. www.unhabitat.org. Retrieved October $5^{\text {th }}$ 2009

Omirin, $\mathrm{M}$ and Nubi, T (2007), Urban Violence, Land Rights and the Environment, paper presented at International Conference on Environmental Economics and Conflict Resolution, University of Lagos

Rogerson, C. (1996), Globalization or informalization? African urban economies in the 1990s http://gellis.org/ Globalisation, Economic Liberalisation and Indian Informal Sector.htm

Rogerson, C. (2001). "Spatial development initiatives in Southern Africa: The Maputo Development Corridor', in Tijdschrift voor
Economische en Sociale Geografie 92 (3), 324-346

Sinai, I. (1998) "Using the home for income generation"; Cities 15(6)417-427

Tipple, G. (2005) "The Place of Home based enterprises in the Informal Sector: Evidence for Cochabamba, New Delhi, Surabaya and Pretoria", Urban Studies, 42(4), 611-632

Tipple, G. (2005) ' Employment and work conditions in home based enterprises in four developing countries: do they constitute "decent work?" Work, Employment and Society, 19(4), 841-853.

Todaro, V. (1978). "A model of labour migration and urban unemployment in lessdeveloped countries." American Economic Review (March).

United Nations Development Programme (2008) Human Development Statistical update www.hdr.undp.org

Yunusa, M. (2011), Planning Cities for Wealth Creation; Public lecture Urban Dialogue Series at University of Lagos 